\title{
Effects of nuisance submerged vegetation on the fauna in Norwegian rivers
}

\author{
Gaute Velle $\mathbb{D} \cdot$ Helge Skoglund · Bjørn T. Barlaup
}

Received: 20 February 2020/Revised: 23 October 2020/Accepted: 11 November 2020/Published online: 18 January 2021

(C) The Author(s) 2020

\begin{abstract}
The abundance of aquatic vegetation is increasing in rivers and lakes worldwide. The aim of this study was to find how the macrophyte Juncus bulbosus Linnaeus affects salmonids and benthic macroinvertebrates in Norwegian rivers. The proliferation of $J$. bulbosus in the study rivers commenced after the development of hydropower in the 1960s and 1970s. J. bulbosus is now considered a nuisance for humans in many areas of the rivers. We found a higher density of juvenile fish and higher density, weight and species richness of invertebrates in areas with $J$. bulbosus than in areas with gravel, suggesting that the vegetation is not limiting fish and invertebrates. This may be because macrophytes increase the surface area and provide shelter, food and a variety of ecological niches. Adult salmonid fish can be negatively affected
\end{abstract}

Guest editors: Ingeborg P. Helland, Michael Power, Eduardo G. Martins \& Knut Alfredsen / Perspectives on the environmental implications of sustainable hydro-power

Electronic supplementary material The online version of this article (https://doi.org/10.1007/s10750-020-04465-x) contains supplementary material, which is available to authorized users.

G. Velle $(\bowtie) \cdot$ H. Skoglund · B. T. Barlaup

NORCE Norwegian Research Centre, Bergen, Norway

e-mail: gvel@norceresearch.no

G. Velle

Department of Biological Sciences, University of Bergen,

Bergen, Norway when their spawning grounds are covered by vegetation. However, overgrowth is not common and may take years since fish clear the river bed of macrophytes during redd digging, indicating competition between macrophytes and fish for riverbed habitat. Our results suggest that one should not assume that outgrowths of macrophytes have negative impacts on the ecosystem. It is important to map all impacts and distinguish nuisance to humans from effects on the ecosystem.

Keywords Freshwater management $\cdot$ Hydropower . Benthic invertebrates $\cdot$ Salmonids $\cdot$ Ecosystem services · Juncus bulbosus

\section{Introduction}

Macrophytes are increasing in abundance in rivers and lakes worldwide (Hussner et al., 2017; Verhofstad et al., 2017; Kagami et al., 2019). Anthropogenic disturbances are often causing outgrowths, e.g. when floating-leaved and emergent vegetation proliferate as a consequence of eutrophication (Egertson et al., 2004; Verhofstad et al., 2017) or when submerged macrophytes proliferate as a consequence of oligotrophication or low-suspended sediment concentrations (Kohler et al., 2010; Ibáñez \& Peñuelas, 2019). In rivers, flow modifications may cause increased macrophyte abundance and thus management approaches are often focused on regulating flow dynamics of the system to control unwanted macrophytes (French \& 
Chambers, 1997; Ochs et al., 2018). The bulbous rush (Juncus bulbosus) is a member of the rush family (Juncaceae) that typically occurs in or by oligotrophic water on acidic to neutral soils in Europe and North America (Brandrud \& Roelofs, 1995; Proćków, 2008). J. bulbosus has spread in the temperate zone, e.g. in northern Europe, Australia, New Zealand, Chile, USA, Canada and Russia (Roelofs, 1983; Aulio, 1987; Svedang, 1992; Brandrud, 2002; Rose, 2007; www. discoverlife.org). Once established, J. bulbosus, aided by asexual budding, will continue to spread through the ecosystem (Moe, 2012). Despite the high number of suggested causes, it has not been possible to find a consistent pattern of environmental variables that explains the expansion (Moe et al., 2013; Schneider et al., 2013). The macrophyte is increasingly abundant in Norway, coinciding with climate change, acidification, nitrogen deposition, eutrophication and liming (Lucassen et al., 2012, 2016; Moe et al., 2013; Schneider et al., 2013). On top of this, hydropower development has added to the significant increases in the abundance of $J$. bulbosus in Norwegian rivers, especially as a consequence of changes in flow dynamics (Rørslett, 1988; Rørslett et al., 1989).

Macrophytes may be ecosystem engineers that alter flow and sediment conveyance and have the ability to cause geomorphological and ecological change. Fine sediments settle in and around J. bulbosus as the buds reach a size that baffle water velocity. The sediment accumulation favours further growth, which may alter the hydrodynamics of river reaches. The buds are normally 10 to $20 \mathrm{~cm}$ long, however, they may be up to 3 $\mathrm{m}$ long and cover the water column to the surface. Such vegetation outgrowth is considered a nuisance because large mats of the plant and the additional accumulated soft sediments interfere with human uses of the waters, such as fishing, boating and swimming (Moe et al., 2013; Verhofstad \& Bakker, 2019). Plant buds also block inlet screens of hydropower facilities. Furthermore, stakeholders, researchers and governmental institutions are worried that the plant threatens economically and ecologically important salmonid species in rivers (Moe, 2012; Moe et al., 2013; personal communication the Norwegian Environment Agency), and implement costly mechanical removal as an abatement measure. Mechanical removal may even have negative effects by spreading the plant downstream.

Information on effects caused by vegetation outgrowth often focuses on the interactions between plants or on accelerated ageing and succession to more terrestrial habitats because of biomass accumulation (Lan et al., 2010). Less is known about effects of $J$. bulbosus on fish and invertebrates. However, surrogate information suggests both potential positive and negative effects caused by the spreading J. bulbosus. Positive effects may arise given that macrophytes provide a variety of ecological niches and habitat heterogeneity to fish, invertebrates, periphytons and diatoms (Warfe \& Barmuta, 2004; McAbendroth et al., 2005). In addition, macrophytes may be beneficial for the nutrient cycling of the ecosystem (Thomaz \& da Cunha, 2010), provide oxygenation of the water (Cowx \& Welcomme, 2004), provide other ecosystem services, such as preventing algal blooms (Hilt et al., 2017), and mitigate greenhouse gas emission (Shi et al., 2019). Macrophytes may have negative effects by decreasing the abundance of fish and macroinvertebrates (Schultz \& Dibble, 2012). Macrophytes may also be harmful for salmonids by reducing dissolved oxygen within the water column during warm weather through accelerated decay (Brooker et al., 1977) and cause elevated hydrogen sulphide concentrations within the hyporheic zone (Groves \& Chandler, 2005). Salmonids are ecologically important fish, native to streams throughout the northern hemisphere, that rely on swift flowing water (Fleming, 1996). Their egg survival varies with hydraulic conditions and substrate size (Fleming, 1996). Aggregation of vegetation and fine sediment can decrease the availability of coarse substrate and reduce the water velocity in areas where salmonids normally dig spawning redds. The quality of the nursery areas for fish fry is reduced if vegetation and sediments create a barrier that limits the available shelter in the riverbed (Heggenes \& Saltveit, 2002), and if macrophytes negatively influence the production of macroinvertebrates (Petr, 2000). Indeed, the diversity and density of macroinvertebrates can be negatively affected if macrophytes reduce the flow of water and the oxygen level, and causes less frequent disturbances (Brooker et al., 1977; Resh et al., 1988; Vinson \& Hawkins, 1998; Beisel et al., 2000).

The motivation for this study was a concern for negative impacts on fish and macroinvertebrates caused by outgrowths of J. bulbosus. We aimed to investigate potential secondary negative effects caused by hydropower development that so far have been overlooked. From a management point of view, it 
is important to distinguish negative effects on the ecosystem from the commonly perceived reduction of recreational values, and to weigh ecological and recreational impacts against the cost of abatement measures. The overall aim of this study was therefore to find how J. bulbosus affects native salmonids (Atlantic salmon Salmo salar Linnaeus, 1758 and brown trout Salmo trutta Linnaeus, 1758) and benthic invertebrates. We tested five hypotheses concerning the effects of $J$. bulbosus on fish and benthic invertebrates: (1) the density and biomass of benthic invertebrates are lower in areas including $J$. bulbosus than in areas with gravel; (2) the density of Atlantic salmon and brown trout juveniles is lower in areas including $J$. bulbosus than in areas with gravel; (3) the species diversity of benthic invertebrates is lower in areas including $J$. bulbosus than in areas with gravel; (4) the fish diet will include less prey from areas with $J$. bulbosus than areas with gravel; and (5) the survival of fish eggs in spawning redds is negatively affected in areas including $J$. bulbosus.

\section{Materials and methods}

We sampled fish and benthic macroinvertebrates in habitats including gravel and in habitats with a $100 \%$ cover of J. bulbosus at five sites in the Rivers Otra, Mandalselva and Matreelva, and habitats with a 50\% cover of J. bulbosus at four of the sites (Fig. 1; Table 1). Buds in the $100 \%$ sites fully covered the riverbed and extended to more than half of the distance to the water surface. Sites with $50 \%$ cover included about equal amounts of J. bulbosus and gravel and where the buds extended up to half of the distance to the water surface. J. bulbosus was not present in gravel habitats. All sampled habitats within one site had a comparable water depth and stream discharge (Table 1), suggesting comparable environmental conditions apart from those governed by J. bulbosus. Habitat patches in deeper sites with $100 \%$ J. bulbosus cover extended for several hundred metres. For these, gravel samples were acquired in smaller patches in the nearest riverbed that consisted of gravel. The rivers were selected because they have dense populations of $J$. bulbosus that in some areas overlay previous spawning grounds for Atlantic salmon and brown trout, while the study sites within the rivers were restricted to neighbouring sites with gravel or $J$. bulbosus. We have records of the distribution of $J$. bulbosus on spawning grounds in Mandalselva spanning the last 15 years and Matreelva over the last 22 years.

\section{Macroinvertebrates}

Macroinvertebrates were sampled with a Surber sampler (Hynes, 1970) with a $30 \times 30 \mathrm{~cm}$ frame by thorough stirring of the substratum to a depth of about $10 \mathrm{~cm}$. In addition, all macrophytes within the sampling frame were cut with garden shears before being transferred to the lab for sorting of macroinvertebrates. Similar habitat covered the area at least within a $1 \mathrm{~m}$ radius, and the maximum distance between habitats including macrophytes and gravel at one study site was about $15 \mathrm{~m}$. All animals were identified using a stereo microscope. Most Trichoptera, Plecoptera, Ephemeroptera, Coleoptera and Gastropoda were identified to species level; the taxonomic resolution varied for the other groups. Planktonic crustaceans in the samples (Ostracoda, Bosmina, Cyclopoida, Chydoridae, Calanoidae, Macrotricidae and Eurycercus lamellatus (O.F.Müller, 1776)) may have originated from low-velocity lotic habitats (such as in situ within the vegetation) (Richardson, 1992) or have been transported from nearby lentic habitats. These were omitted from the analysis of diversity, density and biomass because the fraction of transported animals was unknown and may vary among samples, e.g. as a result of differences in stream flow. We estimated the biomass of the invertebrate samples by drying the samples at $50^{\circ} \mathrm{C}$ for $24 \mathrm{~h}$ before weighing. Cases and shells of Trichoptera, Gastropoda and Mollusca were omitted from the analyses of biomass. The samples were corrected for potential differences in taxonomic resolution before analyses of diversity. This was done by merging taxa with inconsistent taxonomy among samples.

\section{Fish}

The fish densities were assessed using standard point abundance sampling by electrofishing with an electrofishing backpack (Bohlin et al., 1989) in shallow waters $(\mathrm{ca}<0.5 \mathrm{~m})$. We used a point abundance sampling strategy in which numerous small sample units were fished instead of one or a few large samples 

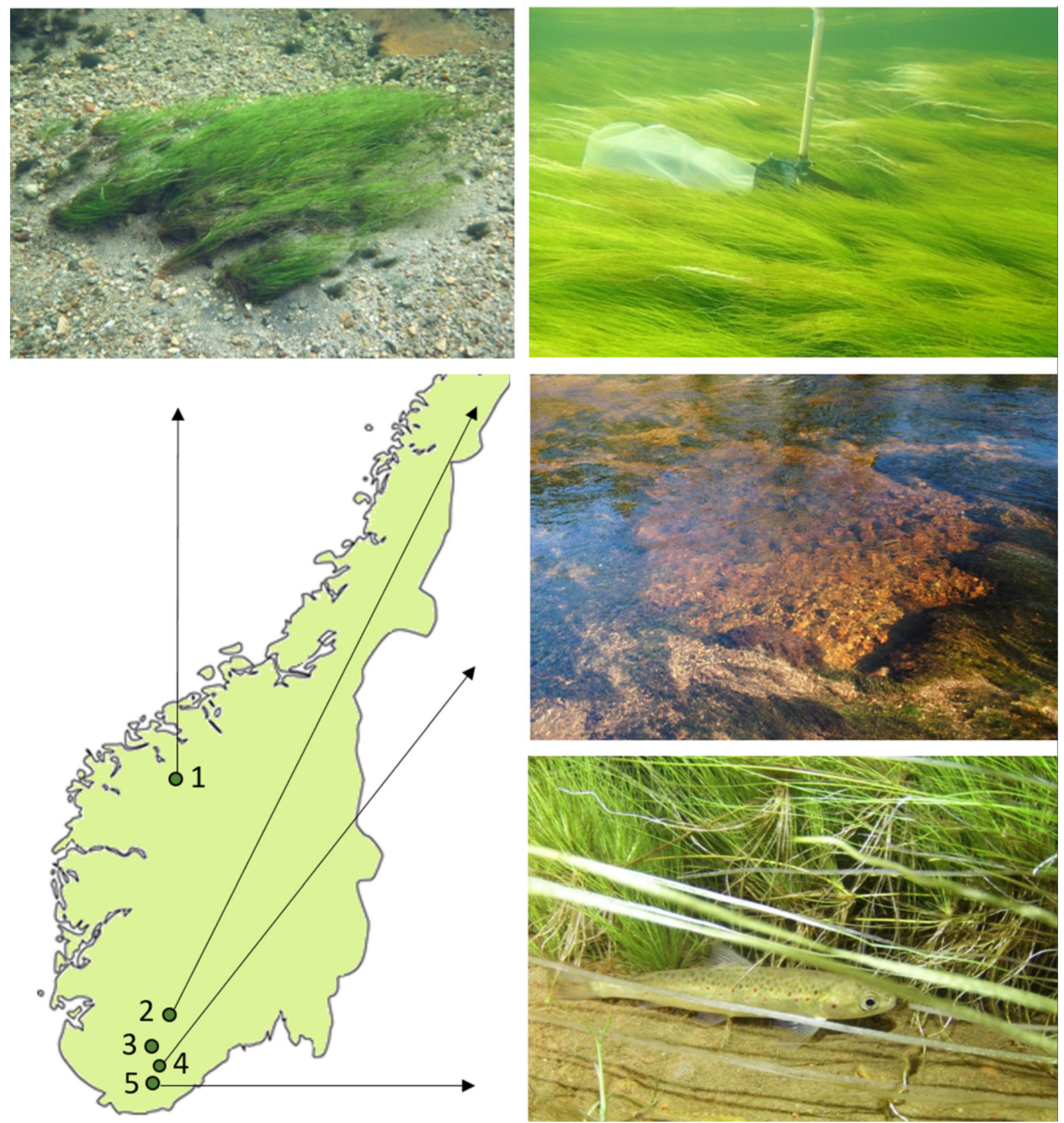

Fig. 1 Map showing the study rivers in southern Norway. 1 Matreelva, 2 Otra, 3 Mandalselva (site Sveindal), 4 Mandalselva (site San $\varnothing$ ), 5 Mandalselva (site Marnardal). Upper left: fine sediments accumulate around a new stand of J. bulbosus. Upper right: sampling of benthic invertebrates in a site with $100 \%$

cover of $J$. bulbosus by use of a Surber sampler. Middle right: a spawning area used by Atlantic salmon (S. salar) surrounded by J. bulbosus. Lower right: An Atlantic salmon fry is hiding in $J$. bulbosus

(Nelva et al., 1979). In deeper waters (1.0 to $2.5 \mathrm{~m}$ ), we used an electrofishing boat (Brousseau et al., 2005). The boat had two array anodes and used the hull as a cathode. Three persons operated the boat: one pilot

and two handlers who netted fish caught by the electric current. The speed of the boat was constant, allowing for a comparison of fish caught per minute among sites. Plots fished by backpack and boat included at 
Table 1 Characteristics of the study sites and sampling performed at the site

\begin{tabular}{llllll}
\hline River & Otra & Mandalselva (Sveindal) & Mandalselva (Sanøy) & Mandalselva (Marnardal) & Matreelva \\
\hline Location ${ }^{\circ} \mathrm{N}$ & 58.97994 & 58.49130 & 58.33419 & 58.21939 & 60.88448 \\
Location $^{\circ} \mathrm{E}$ & 7.665189 & 7.448259 & 7.52995 & 7.51813 & 5.58373 \\
Date $(\mathrm{mm}-\mathrm{yy})$ & $09-15$ & $09-15$ & $08-13$ & $08-13,12-13^{\dagger}$ & $11-11,05-12^{\mathrm{a}}$ \\
Temperature $\left({ }^{\circ} \mathrm{C}\right)$ & 9.5 & 11.0 & 12.6 & $14.0,5.0$ & $6.5,6.8$ \\
Gravel size (mm) & $4-64$ & $1-4$ & $4-64$ & $4-64$ & $1-64$ \\
Inv.habitat & $5 \mathrm{G}, 5100$ & $5 \mathrm{G}, 5100$ & - & $8 \mathrm{G}, 850,8100$ & 7 G, 7 100 \\
Inv.depth (cm) & 150 & $90-100$ & - & $30-40$ & $30-40$ \\
Inv.velo (m/s) & 0.5 & 0.3 & - & $0.8-1.0$ & $0.6-0.7$ \\
Fishing gear & Boat & Boat & Backpack & Backpack & Backpack \\
Fish habitat & G, 50, 100, F & G, 50, 100, F & G, 50, 100, P, A & G, 50, 100, P, A & G, 100, P, A \\
Egg survival & No & No & Yes & Yes & No \\
\hline
\end{tabular}

Inv. benthic macroinvertebrates, Inv.habitat the number of samples acquired from the habitat, G gravel, $5050 \%$ cover of J. bulbosus, $100100 \%$ cover of J. bulbosus, Inv.depth the water depth at the site, Inv.velo the water velocity measured during sampling at the site, $F$ densely populated fields of $J$. bulbosus with smaller patches of gravel, $P$ patchy habitat including $J$. bulbosus and gravel, A reach with anadromous fish

${ }^{\mathrm{a} O n l y}$ invertebrates were sampled on this date

least ca $1 \times 1 \mathrm{~m}$ and about $100 \times 12 \mathrm{~m}$ of homogenous habitats, respectively. Most plots were larger. The minimum size of the plots fished by backpack was set to assure many independent data points. We have not compared fish densities caught by backpack and boat electrofishing because these results are not necessarily comparable. Also, results from the electrofishing boat were not tested for statistical significance since the boat sampled large continuous areas, with few subsamples. These results are still included since the fishing over large areas provide a robust description of the density of fish. All fish were identified and measured for length in the field. About half were killed for analysis of stomach content to assess whether fish prefer prey from certain habitats. Stomachs were stored in alcohol and we counted and identified the content in the lab.

\section{Fish eggs}

We investigated the effect of $J$. bulbosus on the incubation success of anadromous Atlantic salmon and anadromous brown trout by sampling and recording egg survival in 69 nests in two spawning areas in the river Mandalselva (Table 1). The nests were located by surveying the spawning areas for typical redd structures, and we attempted to sample all nests.
The sampling was done in spring prior to hatching. We used visual inspection to quantify $J$. bulbosus growth over the redd, defined as the area of gravel affected by nest digging, and in the immediate area surrounding the redd, defined as the area from the edge of the redd and $1 \mathrm{~m}$ outwards. The eggs in the nests were sampled by excavating carefully with a garden shovel until 10 to 20 eggs were found. Egg survival was registered by recording living and dead eggs. One-eyed egg was sampled from 45 of the nests and brought to the lab for species identification using isoelectric focusing (Mork \& Heggberget, 1984). The remaining eggs were left undisturbed and the redd structure was restored in an attempt to disturb the nests as little as possible.

Numerical analyses

The difference in the total number of fish among habitats was analysed using a generalized linear model (GLM) with a Poisson family error distribution. Predictive variables were habitat (100\% J. bulbosus, $50 \%$ J. bulbosus and gravel) and location (Mandalselva (Sanøy), Mandalselva (Marnardal) and Matreelva). Egg survival (living versus dead eggs) was analysed using a GLM with binomial family error distribution. For the egg survival model, percentage coverage of J. bulbosus at the site was the continuous 
variable and location was the categorical predictor (two sites in the river Mandalselva). Total number of invertebrates and total weight of invertebrates were analysed using a GLM with a Gaussian family error distribution with habitat $(100 \%$ J. bulbosus and gravel) and location (Mandalselva (Marnardal), Mandalselva (Sveindal), Matreeelva and Otra) as categorical predictors. Because 50\% J. bulbosus was only sampled in Mandalselva (Marnardal), this habitat was omitted from the GLM. All models were checked for assumptions and over dispersion using diagnostic plots, and were run in R ( $\mathrm{R}$ Core Team, 2017). A comparison of invertebrate assemblages among sites and the assemblages eaten by fish were done by permutational multivariate analysis of variance (PERMANOVA; Anderson, 2001) in PAST (Version 3.18, January 2018: Hammer et al., 2001) with Bray-Curtis distance measure, 9,999 permutations and correcting the significance level for multiple testing by sequential Bonferroni (Holm, 1979).

Only samples acquired on the same date from any one site were compared since the invertebrate abundance and composition vary across seasons. The diversity of invertebrates was calculated as rarefied number of species for each set of samples $(100 \% \mathrm{~J}$. bulbosus, $50 \% \mathrm{~J}$. bulbosus and gravel) at each site and with 9,999 permutations in EstimateS (Version 9.1.0, June 2013: Colwell, 2013). To ease the interpretation of results, the diversity was extrapolated to the expected number of species that would be found in an augmented sample. This was done using the nonparametric methods described in Colwell et al. (2012).

\section{Results}

Biomass, density, diversity and taxa assemblages

Brown trout dominated at Otra, Matreelva and Sveindal, whereas Atlantic salmon dominated at Sanøy and Marnardal (Table 2). According to the backpack fishing, there was a significant relationship between habitat and number of fish $(P<0.001)$, with a higher number of fish in $100 \% \mathrm{~J}$. bulbosus than in gravel (Fig. 2). Results from the electrofishing boat also indicated a higher number of fish in areas with $100 \% \mathrm{~J}$. bulbosus than in areas with gravel (Fig. 3), but due to sampling method, this was not tested statistically.
The density of invertebrates in habitats having $100 \%$ cover of $J$. bulbosus was significantly higher $(P<0.001)$ than in habitats with gravel (Fig. 4). The chironomids composed the most common group of benthic invertebrates at nearly all sites, defined as the number of individuals, and the number of chironomids explained a large fraction of the observed difference in density (Table 3, see also full species list in Supporting Material). Other common taxa varied among the sites, and often included Oxyethira, Amphinemura sulcicollis (Stephens, 1836), Leptophlebia marginata (Linnaeus, 1767) and Oligochaeta in gravel, and $L$. marginata, Oligochaeta and Nematoda in J. bulbosus (Table 3). When it comes to biomass, the weight of the assemblages was significantly higher in habitats having $100 \%$ cover of $J$. bulbosus than in habitats with gravel $(P<0.05)$ (Fig. 5). The invertebrate assemblages had a significantly different composition in gravel and in $J$. bulbosus in reaches with patchy cover of gravel and J. bulbosus (Mandalselva (Marnardal) and Matreelva), but not different in reaches where $J$. bulbosus covers hundreds of metres of riverbed (Otra and Mandalselva (Sveindal), Table 4). The diversity of the invertebrate assemblages was highest in $J$. bulbosus for three sites and highest in gravel at one site (Fig. 6). These results suggest that hypotheses one and two regarding the density and biomass of benthic invertebrate and density of fish can be rejected, and that hypothesis three regarding diversity also can be rejected. All assumptions were met in the GLMs.

\section{Diet composition of fish}

A total of 101 fish were analysed for stomach content (Table 5). The numerical analysis suggests that the diet composition of fish caught in gravel was significantly correlated to both invertebrate assemblages found in gravel and assemblages found in J. bulbosus, depending on the site (Table 4). The same applies for the diet composition of fish caught in J. bulbosus. There was a significant difference in prey composition between fish caught in gravel and fish caught in $J$. bulbosus in Mandalselva (Marnardal) and no difference for the other sites (Table 4). These results suggest that the fish did not have a preference for feeding habitat, and thereby that hypothesis four can be rejected. 
Table 2 Results from the electrofishing with habitat, fishing effort as number of seconds (s) or number of $1 \mathrm{~m}^{2}$ plots (p) and species and number of fish caught during boat $(\dagger)$ or backpack $(\dagger)$ electrofishing

\begin{tabular}{|c|c|c|c|c|c|}
\hline River site & Habitat & Effort & Salmon & Trout & Other \\
\hline \multirow[t]{3}{*}{ Otra $\uparrow$} & Gravel & $1,122 \mathrm{~s}$ & & 7 & 1 Bleke \\
\hline & 50 & $1,703 \mathrm{~s}$ & & 10 & 1 Minnow \\
\hline & 100 & $1,599 \mathrm{~s}$ & & 31 & \\
\hline Mandalselva & Gravel & $501 \mathrm{~s}$ & & 2 & \\
\hline \multirow[t]{2}{*}{$($ Sveindal $) \dagger$} & 50 & $231 \mathrm{~s}$ & & 13 & \\
\hline & 100 & $330 \mathrm{~s}$ & & 21 & \\
\hline Mandalselva & Gravel & $25 \mathrm{p}$ & 15 & 1 & \\
\hline \multirow[t]{2}{*}{$(\operatorname{San} \varnothing \mathrm{y}) \ddagger$} & 50 & $16 \mathrm{p}$ & 10 & & \\
\hline & 100 & $20 \mathrm{p}$ & 17 & 1 & \\
\hline Mandalselva & Gravel & $21 \mathrm{p}$ & 32 & & \\
\hline \multirow[t]{2}{*}{ (Marnardal) $\ddagger$} & 50 & $32 \mathrm{p}$ & 40 & 3 & \\
\hline & 100 & $26 \mathrm{p}$ & 44 & 2 & 3 Lamprey \\
\hline \multirow[t]{2}{*}{ Matreelva $\ddagger$} & Gravel & $50 \mathrm{p}$ & & 17 & \\
\hline & 100 & $50 \mathrm{p}$ & & 58 & \\
\hline
\end{tabular}

$5050 \%$ Cover of J. bulbosus, 100 100\% cover of J. bulbosus. Species of fish: brown trout (S. trutta), Atlantic salmon (S. salar), bleke = landlocked salmon (S. salar ssp.), minnow (Phoxinus phoxinus (Linnaeus, 1758)), river lamprey (Lampetra fluviatilis (Linnaeus, 1758))

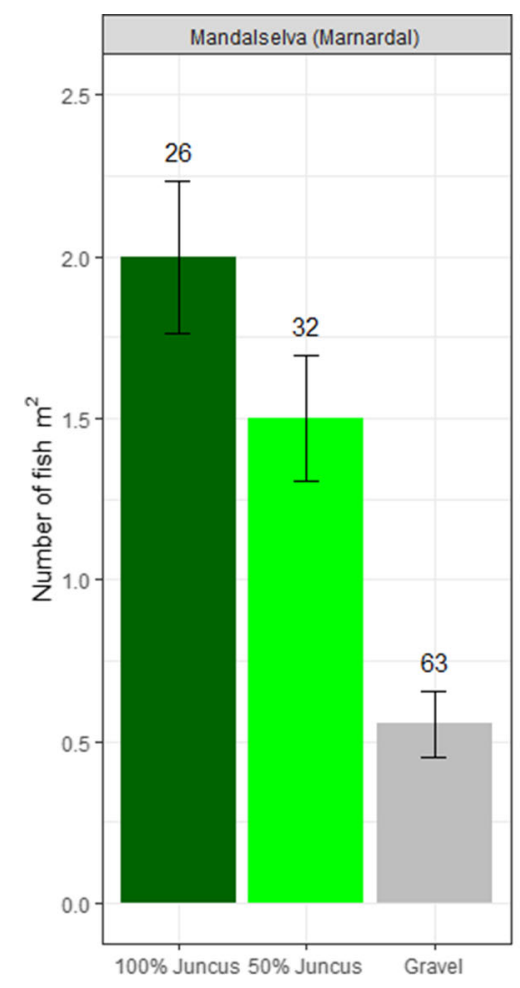

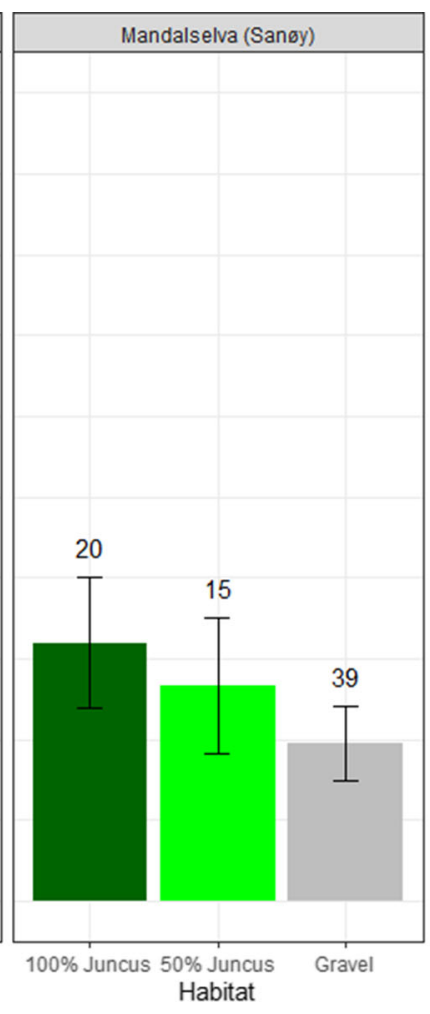

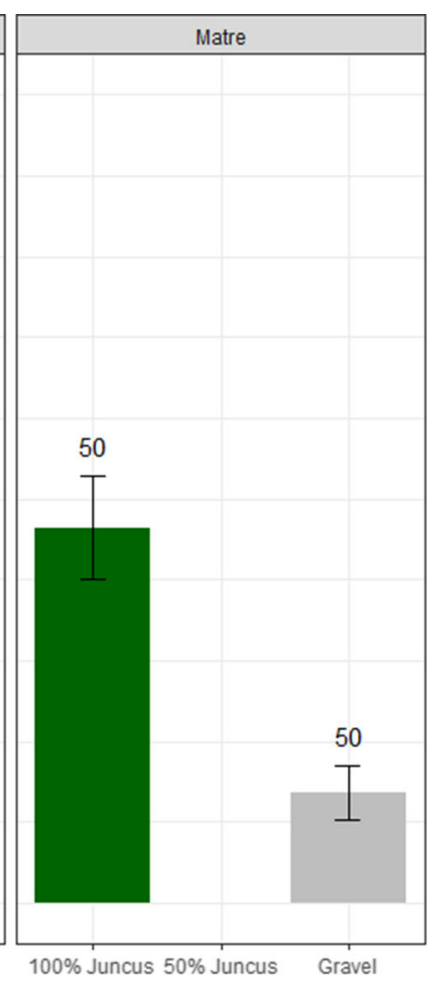

Fig. 2 A comparison of the density of fish among habitats. The fish were sampled by use of backpack electrofishing and the results are given as number of fish per $\mathrm{m}^{2}$. There was a significant difference $(P<0.001)$ between densities in gravel and in $100 \% \mathrm{~J}$. bulbosus. The error bars indicate the standard error 


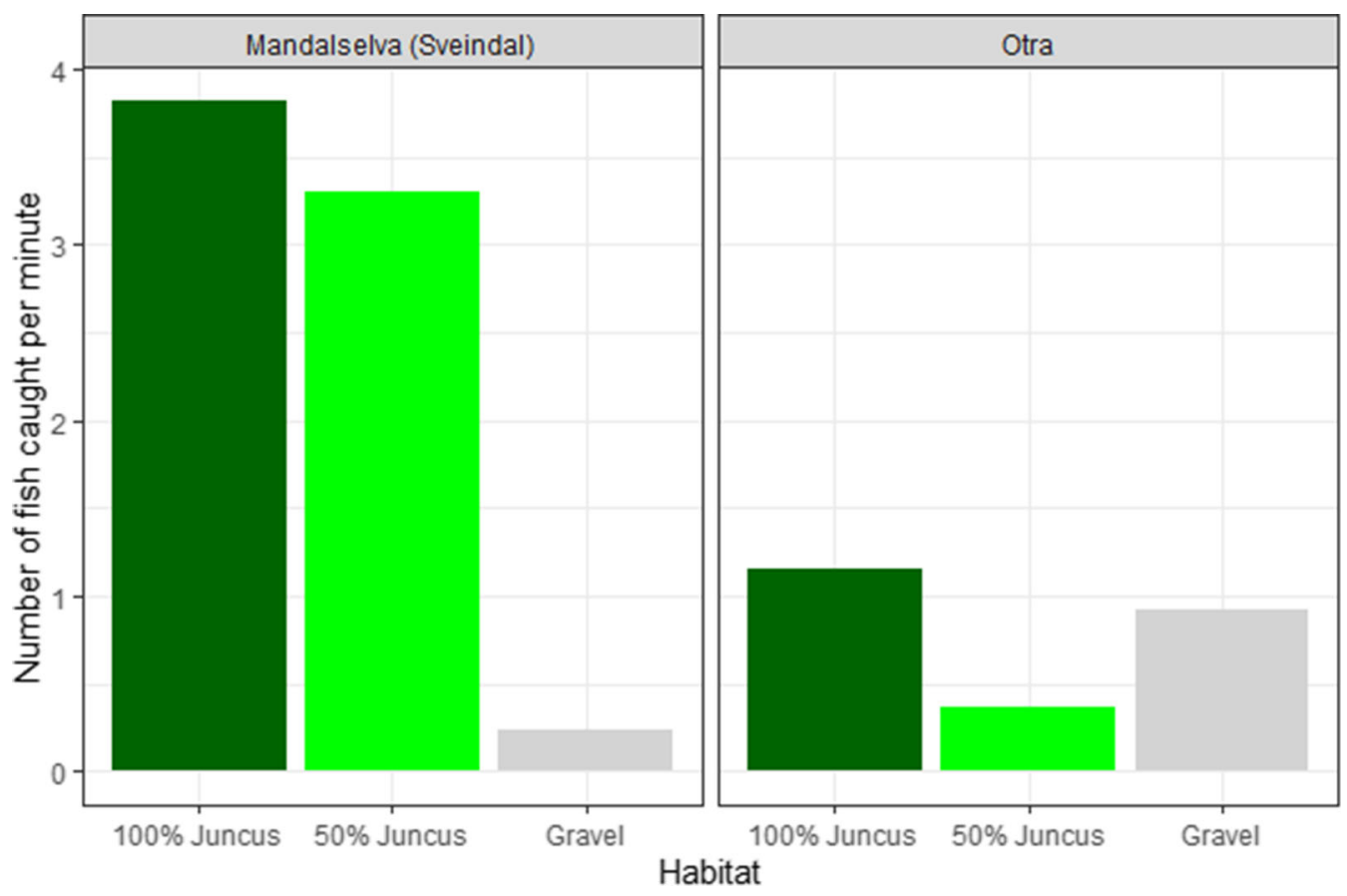

Fig. 3 A comparison of the density of fish among habitats. The fish were sampled by use of an electrofishing boat and the results are given as number of fish caught per minute. The results were not tested for statistical significance due to the sampling method

Fish egg survival

Species identification of eggs indicate that Atlantic salmon and brown trout spawned in 43 and 2 of the nests, respectively, whereas eggs from the remaining nests were not sampled for species identification. The average cover of J. bulbosus in the redds was $<1 \%$ (range 0-20\%), whereas the average cover of $J$. bulbosus in the areas surrounding the redds was $17 \%$ (range 0-90\%). The average egg survival was $89.2 \%$, and there was no significant relationship between cover of J. bulbosus and egg survival. This suggests that hypothesis five on the survival of fish eggs can be rejected. However, it should be noted that the results on eggs are based only on two sites in Mandalselva.

\section{Discussion}

Effects on benthic invertebrates

Many taxa occurred both in habitats including gravel and $J$. bulbosus, however, the density, biomass and diversity were higher in habitats with $J$. bulbosus. Some of the additional taxa in J. bulbosus were burrowers, reflecting an accumulation of fine sediments that favours body shapes adapted for burrowing. Although the chironomids were not identified to species, a major part of the chironomid assemblage was found on macrophyte leaves, suggesting a scraping or piercing feeding mode.

The density and structure of macroinvertebrates are directly and indirectly influenced by macrophytes through physical and biotic characteristics of the habitat (e.g. Feldman, 2001), and some macroinvertebrates are closely associated with macrophytes (Cattaneo et al., 1998; Habib \& Yousuf, 2015). The relationship between macrophytes and invertebrates can either be trophic, spatial or both (Habib \& Yousuf, 2015). Specifically, invertebrates use vegetation and periphyton growing on vegetation as a source of food (Gregg \& Rose, 1985; Thomaz \& da Cunha, 2010), use vegetation as attachment (Keast, 1984; Armitage et al., 1995) and hide from predators and unfavourable conditions in the structure they provide (Harrod, 1964; Gilinsky, 1984). An increased density and diversity associated with $J$. bulbosus may be caused by a complex three-dimensional structure and many small spaces that support high numbers of smaller organisms, thereby enhancing production (Thomaz \& da 


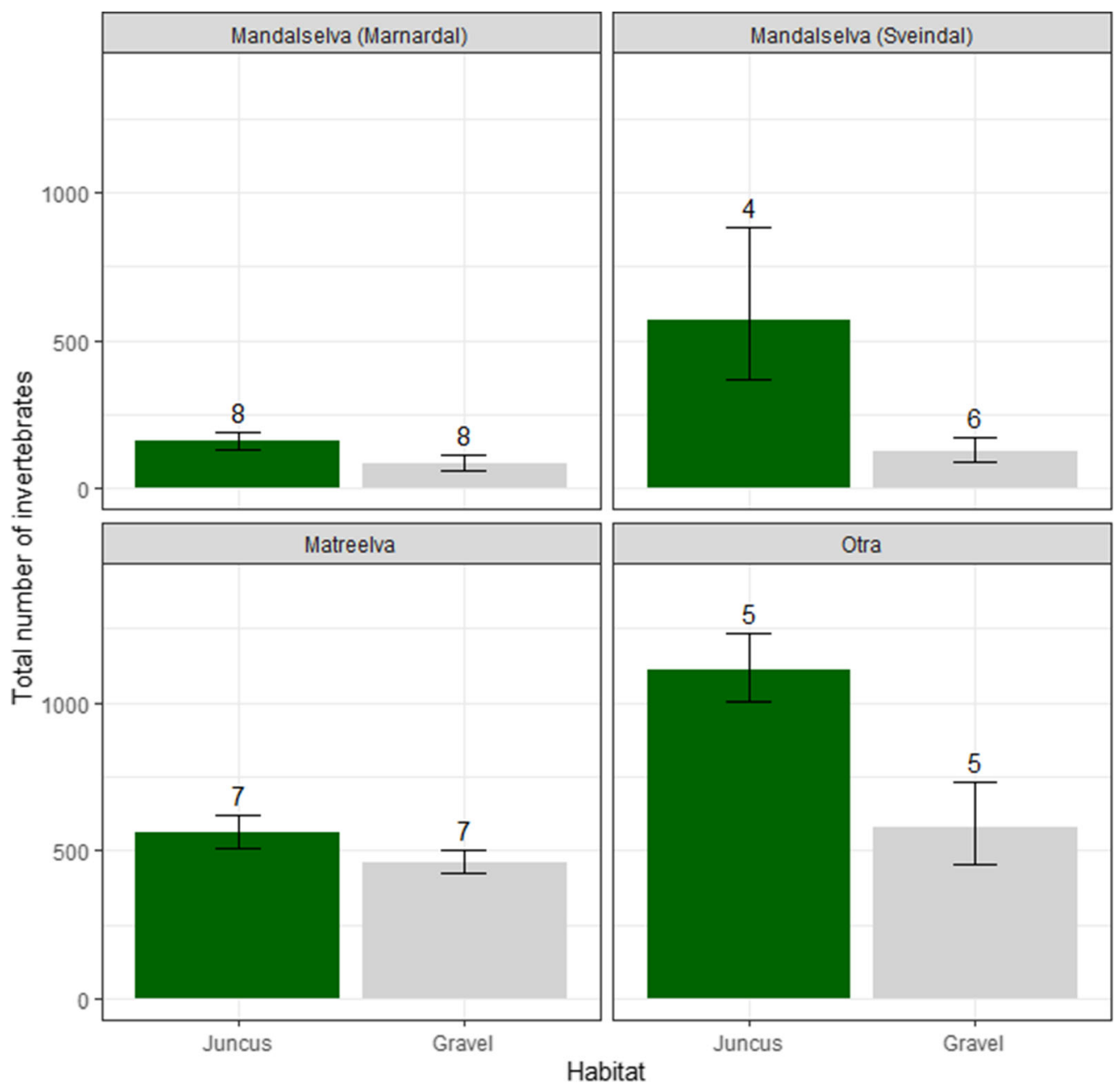

Fig. 4 Density of benthic invertebrates in habitats including gravel and habitats including $100 \%$ J. bulbosus. The reaches in Otra and Mandalselva (Sveindal) include areas where $J$. bulbosus covers hundreds of metres of riverbed and where the sampled gravel sites were within smaller patches of gravel no more than $15 \mathrm{~m}$ from the sampled J. bulbosus sites, while the

Cunha, 2010). Finely divided leaves, such as those characteristic of $J$. bulbosus, provide greater surface area and support larger and more varied populations of benthic invertebrates than macrophytes with simple leaves (Krecker, 1939; Rosine, 1955). This has also been demonstrated in rivers and canals where invasive Ranunculus sp. support large invertebrate communities (Garner et al., 1996; Monahan \& Caffrey, 1996). However, complexity may not always cause higher diversity and density of macroinvertebrates. For example, in some Iceland streams (mean around $5^{\circ} \mathrm{C}$ from May to June), Scrine et al. (2017) found no effect reaches in Matreelva and Mandalselva (Marnardal) include areas with patchy habitats of $J$. bulbosus and gravel. There was a significant difference $(P<0.001)$ between densities in gravel and in J. bulbosus. Error bars indicate the standard error and the numbers above the bar indicate the number of samples

of habitat complexity on the macroinvertebrate abundance.

\section{Effects on juvenile fish}

The higher density of macroinvertebrates in areas with $J$. bulbosus suggests that reaches with $J$. bulbous can support a larger population of fish. Macrophytes provides two critical needs for the juvenile fish-food and shelter. Shelter may include cavities created by stones, dead twigs and trees or macrophytes (Armstrong et al., 2003). Macrophytes may also decrease 
Table 3 A comparison of the most common taxa sampled in gravel and in $100 \%$ J. bulbosus at each river site
The density is given as number of animals per $\mathrm{m}^{2}$. The taxa are sorted in decreasing density

\begin{tabular}{|c|c|c|c|c|}
\hline Site & Taxa in gravel & Density & Taxa in J. bulbosus & Density \\
\hline \multirow[t]{8}{*}{ Matreelva } & Chironomidae & 3,009 & Chironomidae & 4,950 \\
\hline & Oxyethira sp. & 851 & Oxyethira sp. & 836 \\
\hline & Amphinemura sulcicollis & 313 & Leptophlebia marginata & 105 \\
\hline & Helobdella stagnalis & 236 & Empididae & 62 \\
\hline & Leptophlebia marginata & 152 & Oligochaeta & 59 \\
\hline & Amphinemura borealis & 81 & Nematoda & 56 \\
\hline & Acari & 68 & Amphinemura sulcicollis & 49 \\
\hline & Empididae & 63 & Polycentropus flavomaculatus & 49 \\
\hline \multirow{8}{*}{$\begin{array}{l}\text { Mandalselva } \\
\text { (Marnardal) }\end{array}$} & Chironomidae & 8,351 & Chironomidae & 1,593 \\
\hline & Ostracoda & 614 & Hydropsyche siltalai & 337 \\
\hline & Amphinemura borealis & 414 & Amphinemura borealis & 274 \\
\hline & Oligochaeta & 275 & Oligochaeta & 193 \\
\hline & Pisidium sp. & 174 & Leuctra fuscaldigitata & 192 \\
\hline & Amphinemura sulcicollis & 124 & Hydropsyche pellucidula & 169 \\
\hline & Eurycercus lamellatus & 122 & Acari & 112 \\
\hline & Leuctra fuscaldigitata & 90 & Ostracoda & 67 \\
\hline \multirow[t]{8}{*}{ Otra } & Chironomidae & 5,897 & Chironomidae & 10,252 \\
\hline & Oligochaeta & 813 & Oligochaeta & 1,158 \\
\hline & Nematoda & 133 & Nematoda & 320 \\
\hline & Acari & 129 & Acari & 242 \\
\hline & Oxyethira sp. & 58 & Ostracoda & 233 \\
\hline & Leptophlebia marginata & 16 & Oxyethira sp. & 151 \\
\hline & Empididae & 16 & Eurycercus lamellatus & 115 \\
\hline & Apatania sp. & 13 & Pisidium sp. & 62 \\
\hline \multirow{8}{*}{$\begin{array}{l}\text { Mandalselva } \\
\text { (Sveindal) }\end{array}$} & Oligochaeta & 504 & Chironomidae & 4,244 \\
\hline & Chironomidae & 311 & Oligochaeta & 3,644 \\
\hline & Nematoda & 59 & Oxyethira sp. & 189 \\
\hline & Radix balthica & 7 & Nematoda & 178 \\
\hline & Ceratopogonidae & 7 & Leptophlebia marginata & 156 \\
\hline & & & Ceratopogonidae & 122 \\
\hline & & & Kageronia fuscogrisea & 44 \\
\hline & & & Neureclipsis bimaculata & 44 \\
\hline
\end{tabular}

available shelter near stands if reduced water velocity causes aggregation of fine sediments. The availability of shelter may significantly influence the production of fish (Finstad et al., 2007). In terms of food, vegetation can have negative effects on fish if the encounter rates with macroinvertebrates decrease and positive effects if the production of macroinvertebrates increases (Petr, 2000). A positive effect from artificial vegetation on brown trout fry was also found in Sweden (Eklöv \& Greenberg, 1998), whereas physical removal of Ranunculus had no significant impact on salmon and trout fry in the River Spey, Scotland (Laughton et al., 2008).

Still, the higher density of fish juveniles that we found in habitats with J. bulbosus is somewhat surprising because suitable habitats for Atlantic salmon fry and parr are assumed to include gravelto-boulder substratum (Heggenes, 1990) and because macrophytes alter the river bed habitat and may reduce the carrying capacity of salmon parr (Roussel et al., 1998). Either the fish hide in the vegetation and eats what is available there, or the fish find shelter in the vegetation and emerge to feed on drifting 


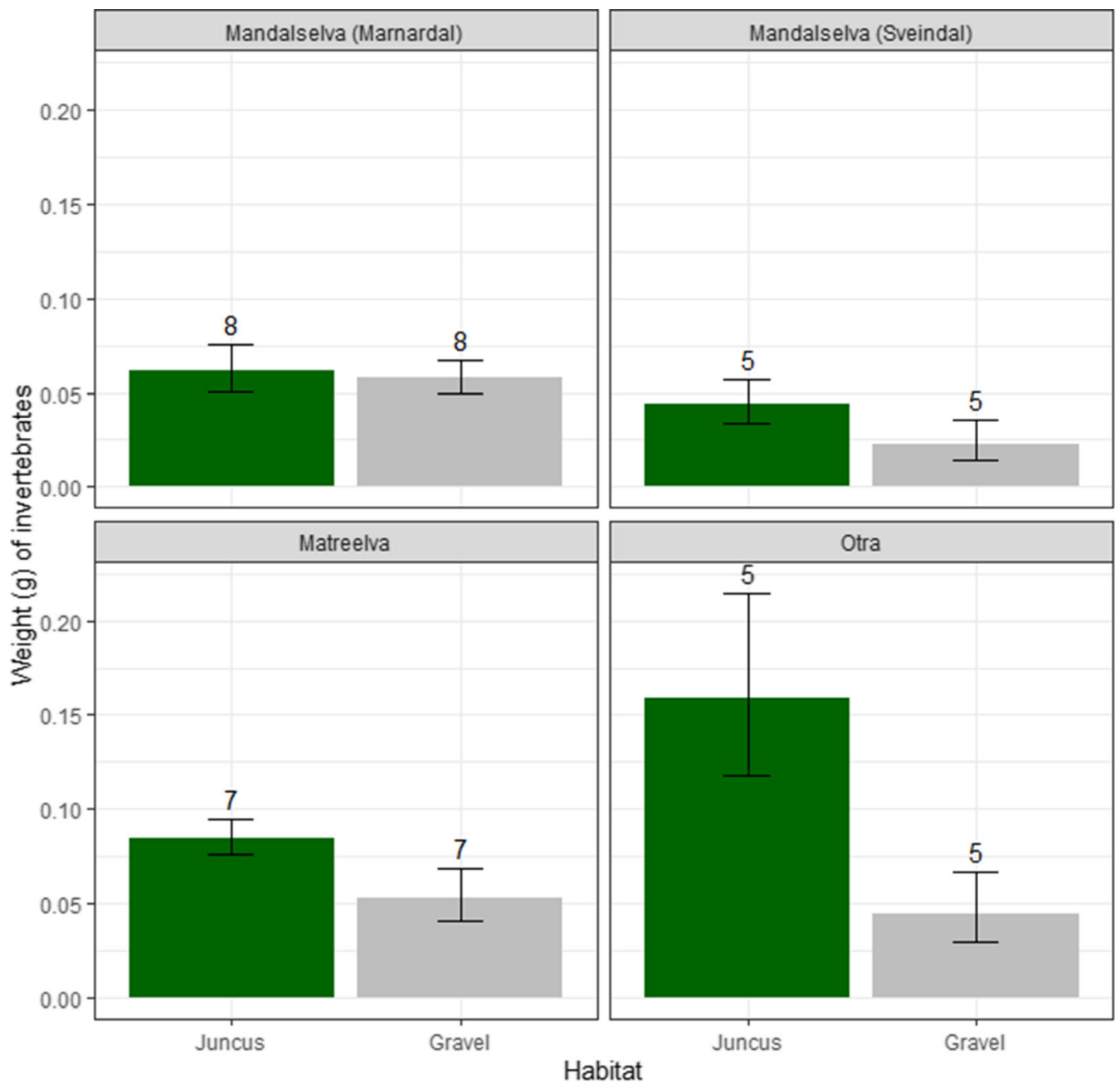

Fig. 5 Weight of the benthic invertebrate samples in habitats including gravel and habitats including $100 \%$ J. bulbosus. The reaches in Otra and Mandalselva (Sveindal) include areas where $J$. bulbosus covers hundreds of metres of riverbed and where the sampled gravel sites were within smaller patches of gravel no more than $15 \mathrm{~m}$ from the sampled J. bulbosus sites, while the

invertebrates. The fish stomach content is not significantly related to the assemblages found in gravel or in vegetation, suggesting that the fish feed from a different source, for example a mixture or drift. This also suggests that the effects of macrophyte on fish are context dependent and depend on the initial availability of shelter in the underlying substratum. For example, the presence of macrophytes may be more beneficial in terms of fish production in areas where availability of shelter and/or food is limited in the first place. reaches in Matreelva and Mandalselva (Marnardal) include areas with patchy habitats of $J$. bulbosus and gravel. There was a significant difference $(P<0.05)$ between weights in gravel and in $J$. bulbosus. Error bars indicate the standard error and the numbers above the bar indicate the number of samples

\section{Competition between spawning fish and $J$. bulbosus}

Rooted macrophytes require space for growth and may significantly lower water velocities and facilitate deposition of fine sediments where they take root, thereby decreasing the quality and the available area required by fish for spawning. If the cover is too extensive, spawners will not find it suitable. Our monitoring of $J$. bulbosus on spawning grounds in Mandalselva and Matreelva indicates similar processes (Skoglund et al., 2006; Gabrielsen et al., 2011). 
Table 4 Comparison of invertebrate assemblages in habitats including gravel, habitats with Juncus bulbosus, invertebrates eaten by fish caught in gravel (stomach gravel) and invertebrates eaten by fish caught in J. bulbosus (stomach Juncus)

\begin{tabular}{lllll}
\hline Habitats & Matreelva & Otra & Mandalselva (Sveindal) & Mandalselva (Marnardal) \\
\hline Stomach gravel vs stomach Juncus & 1.1 & 2.1 & 2.5 & $4.9^{*}$ \\
Stomach gravel vs gravel & $9.8^{* *}$ & $82.6^{* *}$ & 1.8 & 3.2 \\
Stomach gravel vs Juncus & $14.4^{* *}$ & $83.4^{*}$ & $10.6^{*}$ & 2.5 \\
Stomach Juncus vs gravel & $11.7^{* *}$ & $45.4^{* *}$ & 0.4 & $4.6^{*}$ \\
Stomach Juncus vs Juncus & $16.2^{* *}$ & $64.0^{* *}$ & 7.6 & $3.8^{*}$ \\
Gravel vs Juncus & $6.5^{*}$ & 2.1 & 0 & $7.7^{*}$ \\
$50 \%$ Juncus vs stomach gravel & na & na & na & $5.4^{*}$ \\
$50 \%$ Juncus vs stomach Juncus & na & na & na & $6.4^{* *}$ \\
$50 \%$ Juncus vs gravel & na & na & na & $8.0^{*}$ \\
$50 \%$ Juncus vs Juncus & na & na & na & $9.4^{*}$ \\
\hline
\end{tabular}

The numbers denote $F$ values with statistical significance $(* P<0.05$ and $* * P<0.01)$ from a PERMANOVA, where significance indicates a difference

na Not available

In river Matreelva, J. bulbosus started growing on the most important spawning area for brown trout in the late 1990s. The area was cleared of macrophytes and restored for spawning in 2001/2002. Use by spawning fish subsequently increased and held the macrophyte at bay during the subsequent 12 years. The process commences when plant buds spread inwards from the perimeter of the spawning bed, whereupon fish clear the area of vegetation and fine sediments when they dig nesting redds (Fig. 1). Here, gravel riverbed is in a limited supply relative to demand from spawning fish and $J$. bulbosus, suggesting interspecific competition for riverbed. The egg survival is likely normal in these patchy habitats of gravel surrounded by J. bulbosus. It may be beneficial to manage the river and clear selected areas of $J$. bulbosus before the vegetation cover is too extensive, thereby also avoiding accumulation of fine sediments. Reduction of spawning bed quality by submerged vegetation has also been reported for Atlantic salmon and brown trout in the River Spey in Scotland (Laughton et al., 2008) and for Chinook salmon (Oncorhynchus tshawytscha Walbaum, 1792) in a regulated central California river (Merz et al., 2008). In south-western Norway, growth of $J$. bulbosus occurs in spawning areas in 4 of 53 investigated rivers (Matreelva, Romarheimselva, Teigdalselva and Mandalselva) to an extent that reduces the spawning of anadromous fish (personal observation during snorkelling surveys that we have performed annually for 15 years).
Overall effects on fish

An increased abundance of fish in areas with aquatic macrophytes has been observed elsewhere, especially in areas with limited shelter. For example, the density of fish in the Potomac River was two to seven times higher in areas with vegetation than in areas without vegetation (Killgore et al., 1989). However, weedcutting did not influence the fish population in the River Perry (Swales, 1982). We may expect that complexity added by macrophytes provides a higher number of habitats and increases the abundance of food for fish. The effect of macrophytes may also be size-dependent where smaller fish are better able to use the complexity of the habitat and its cavities, whereas larger fish are limited in their free movement and use of spawning habitats. Night snorkelling observations suggest that the spawners use smaller corridors with gravel substrate within the dense fields of $J$. bulbosus (personal observations). However, we cannot conclude on the habitat use of spawning fish because they are difficult to see in the vegetation and because they usually escape from electrofishing. Intermediate growth of the macrophytes may be advantageous because this allows for young fish to find shelter, rarely limits the available area for spawning and promotes the density of invertebrates. According to our results, a dense macrophyte cover does not represent a limiting factor for juvenile fish or invertebrates. 

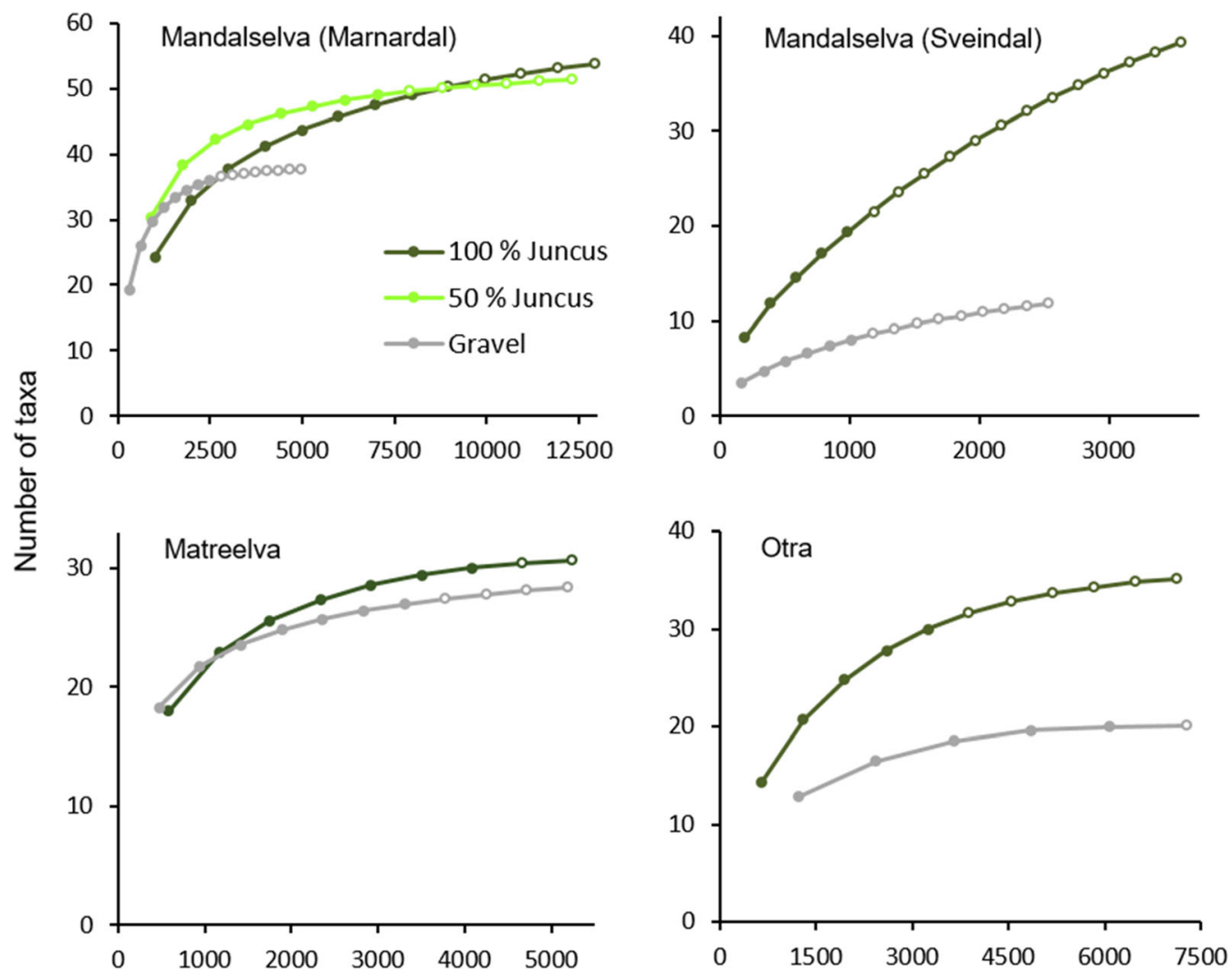

Number of specimen

Fig. 6 Individual-based taxa accumulation curves for benthic invertebrates in A Mandalselva (Marnardal), B Matreelva, C Mandalselva (Sveindal) and D Otra. The upper two sites include river reaches with patchy habitats of J. bulbosus and gravel, while the lower two sites include reaches where $J$. bulbosus covers hundreds of metres of riverbed and with smaller patches of gravel. A closed marker indicates a sample that is based on counts, while an open marker indicates an extrapolation

Table 5 Number of fish analysed for stomach content for each site and habitat, and details on the number of prey items in the stomachs

\begin{tabular}{lcccclrrr}
\hline & $\begin{array}{l}\text { Matreelva } \\
\text { Juncus }\end{array}$ & Gravel & $\begin{array}{l}\text { Otra } \\
\text { Juncus }\end{array}$ & Gravel & $\begin{array}{l}\text { Mandalselva (Sveindal) } \\
\text { Juncus }\end{array}$ & Gravel & \multicolumn{2}{c}{$\begin{array}{l}\text { Mandalselva (Marnardal) } \\
\text { Guncel }\end{array}$} \\
\hline Number of fish & 23 & 7 & 10 & 11 & 5 & 5 & 24 & 16 \\
Maximum & 272 & 35 & 102 & 301 & 8 & 10 & 123 & 3 \\
Minimum & 16 & 8 & 4 & 6 & 1 & 3 & 4 & 36 \\
Median & 16 & 20 & 52 & 21 & 5 & 6 & 27 & 33 \\
Average & 66 & 20 & 55 & 46 & 5 & 6 & 33 & 45 \\
\hline
\end{tabular}

Maximum, minimum, median and average refer to the number of identifiable prey items in the fish stomachs

Juncus J. bulbosus

Since the fish communities in the study rivers are dominated either by Atlantic salmon or by brown trout (Table 2), we have not investigated species-specific effects or effects on the population structure of fish. Species-specific effects are likely in sympatric populations because brown trout is considered an 
opportunistic species compared to Atlantic salmon, has a greater phenotypic plasticity and more often is found in stagnant water (Valiente et al., 2010; Jonsson \& Jonsson, 2011). This suggests that extensive macrophyte growth may alter the balance between Atlantic salmon and brown trout in favour of trout.

With respect to population structure, high rates of survival relative to food availability can potentially lead to over-populated rivers including stunted stationary fish with small bodies and oversized heads. This has been observed for populations of brown trout in lakes (Borgstrøm, 1994), and may also apply to freshwater resident salmonid populations in rivers.

\section{Potential fishing bias}

Electrofishing is the most used method for sampling fish in rivers (Cowx \& Lamarque, 1990; Dunham et al., 2015). We used point sampling, which is a more suitable method than continuous sampling for fry in lowland rivers (Janáĉ \& Jurajda, 2007). However, there are weaknesses involved when electrofishing is used to assess population densities, especially effects of avoidance and hiding behaviour of the fish on fishing efficiency (Bohlin et al., 1989). As is common during electrofishing, fish may seek shelter when a person approaches. Both areas with gravel and areas with $J$. bulbosus include cavities where the fish can hide. However, an unknown number of fish may potentially move between habitats when a person approaches. Differences in fishing efficiency may arise if fish are not detected, and especially if fish remain in the substrate or vegetation after being stunned or are unaffected by electrofishing because the substrate acts as a conductive shield (Beaumont et al., 2002). In addition, results from electrofishing may vary according to time of day, water temperature, conductivity, substrate type, species and fish length (Scholten, 2003). The swift stream flow in our study sites suggests similar temperatures and conductivity among sampling points. Also, the fish species and fish size were similar among habitats. However, the substrate included more mud in samples with $J$. bulbosus. Reduction of the fishing range over muddy substrate can be 20-30\% compared with coarse gravel (Scholten, 2003). Observations in the field (e.g. time before fish emerged) support that fishing efficiency was reduced in vegetation compared to gravel. Since a standardized sampling may provide a means to assess trends (Bonar et al., 2009), we adhered to a standardized sampling protocol and attempted to correct for potential bias by fishing many points and repeating the electric current at any one point until no fish emerged. It is still likely that the density of fish in J. bulbosus is underestimated and represent a minimum estimate compared to the density in gravel. This supports the conclusion that there are more fish in J. bulbosus than in gravel.

Potential secondary effects caused by hydropower

The macrophyte vegetation in natural settings depends on river type, which is determined by stream size, water chemistry, flow velocity, substratum composition and temperature (Fabris et al., 2009). In regulated rivers, excessive macrophyte abundance can be a less well-known but highly undesirable effect (Rørslett, 1988; Rørslett et al., 1989), most likely resulting from altered temperatures, water flow and ice regimes (e.g. French \& Chambers, 1997; Franklin et al., 2008). It is not easy to foresee ecological consequences caused by an increase in macrophyte abundance. Although hydropower can have direct negative effects on the production of fish (Johnsen et al., 2010; Young et al., 2011) and on the biological diversity and density of benthic invertebrates (Englund \& Malmqvist, 1996; Quadroni et al., 2017), our results suggests few, if any, negative effects caused by J. bulbosus. The expanding macrophyte is likely not limiting the density of fish and invertebrates or the species diversity of invertebrates in the regulated rivers in our study. It seems potential negative impacts on the animal community caused by the expanding macrophyte, at least under some circumstances, are outweighed by positive impacts. Outgrowths of this macrophyte in Norwegian rivers therefore do not appear to be of pressing concern to conservation of the ecological integrity of the fauna.

\section{Conclusions}

The effects we have studied are based on the current situation concerning spread and density of J. bulbosus in Norway. It is likely that a spread to new areas will have a neutral to beneficial effect on the diversity of invertebrates and on the production of fish and invertebrates up to a high vegetation density. Where spawning areas of fish are in short supply, they can be 
negatively affected at high vegetation densities. However, overall beneficial effects are possible even above vegetation densities that might negatively affect spawning. This is because vegetation may contribute significantly to increased habitat quality by increasing the availability of shelter, surface area, food and providing a higher variety of ecological niches.

It may still be necessary to control outgrowths of macrophytes in certain areas, e.g. when it interferes with recreational use of the water, clogs hydroelectric dams and intakes to power plants, or covers important spawning areas. When it comes to the impact of weedcutting, Haslam (1978) suggests that invertebrates, fish and plants are best conserved in streams when a quarter of the volume of the river is occupied by plants, while Kern-Hansen (1978) suggests optimal conditions for invertebrates when half of the river is covered by plants. In most rivers, however, biocontrol of $J$. bulbosus should not be performed for the sake of fish and invertebrates. This research reflects the complexity for managing agencies of deciding how to deal with nuisance species. One should not assume, as was done when $J$. bulbosus spread in Norway, that species that spread and become more abundant have negative impacts on all parts of the ecosystem. Decisions on abatement measures that are not knowledge-based can lead to a waste of conservation resources and in the worst case be harmful for the ecosystem, e.g. by reducing the quality of the habitat and the environment by relocating sediments and roots.

Acknowledgements We would like to thank the Juncus Project in Southern Norway (Krypsivprosjektet på Sørlandet) for funding and valuable cooperation. We would also like to thank Torunn Landås and Arne Johannessen for identifying invertebrates, Jon Museth for helping with the boat electrofishing, Knut Wiik Vollset for valuable comments and help on numerical analyses, and Robert Lennox and Shad Mahlum for valuable comments and linguistic corrections. Licenses to perform electrofishing were granted from the County Governors. Two anonymous journal reviewers provided in-depth comments that helped to improve the quality of the manuscript.

Funding Open Access funding provided by University of Bergen.

\section{Compliance with ethical standards}

Conflict of interest The authors have no conflicts of interest to declare.
Open Access This article is licensed under a Creative Commons Attribution 4.0 International License, which permits use, sharing, adaptation, distribution and reproduction in any medium or format, as long as you give appropriate credit to the original author(s) and the source, provide a link to the Creative Commons licence, and indicate if changes were made. The images or other third party material in this article are included in the article's Creative Commons licence, unless indicated otherwise in a credit line to the material. If material is not included in the article's Creative Commons licence and your intended use is not permitted by statutory regulation or exceeds the permitted use, you will need to obtain permission directly from the copyright holder. To view a copy of this licence, visit http://creativecommons.org/licenses/by/4.0/.

\section{References}

Anderson, M. J., 2001. A new method for non-parametric multivariate analysis of variance. Austral Ecology 26: 32-46.

Armitage, P. D., P. S. Cranston \& L. C. V. Pinder, 1995. The Chironomidae: Biology and Ecology of Non-biting Midges. Chapman and Hall, London.

Armstrong, J. D., P. S. Kemp, G. J. A. Kennedy, M. Ladle \& N. J. Milner, 2003. Habitat requirements of Atlantic salmon and brown trout in rivers and streams. Fisheries Research 62: $143-170$.

Aulio, K., 1987. Rapid decline of mass occurrences of Juncus bulbosus in a deacidified freshwater reservoir. Memoranda Societatis pro Fauna et Flora Fennica 63: 41-44.

Beaumont, W., A. Taylor, M. Lee \& J. Welton, 2002. Guidelines for Electric Fishing Best Practice.

Beisel, J. N., P. Usseglio-Polatera \& J. C. Moreteau, 2000. The spatial heterogeneity of a river bottom: a key factor determining macroinvertebrate communities. Hydrobiologia 422: 163-171.

Bohlin, T., S. Hamrin, T. G. Heggberget, G. Rasmussen \& S. J. Saltveit, 1989. Electrofishing - theory and practice with special emphasis on salmonids. Hydrobiologia 173: 9-43.

Bonar, S. A., W. A. Hubert \& D. W. Willis, 2009. Standard Methods for Sampling North American Freshwater Fishes. American Fisheries Society, Bethesda.

Borgstrøm, R., 1994. Production in a lacustrine brown trout population with large recruitment potential and low natural mortality: implications for management. North American Journal of Fisheries Management 14: 488-499.

Brandrud, T. E., 2002. Effects of liming on aquatic macrophytes, with emphasis on Scandinavia. Aquatic Botany 73: 395-404.

Brandrud, T. E. \& J. G. M. Roelofs, 1995. Enhanced growth of the macrophyte Juncus bulbosus in S Norwegian limed lakes. A regional survey. Water, Air and Soil Pollution 85: 913-918.

Brooker, M. P., D. L. Morris \& R. J. Hemsworth, 1977. Mass mortalities of adult salmon, Salmo salar, in the R. Wye, 1976. Journal of Applied Ecology 14: 409-417. 
Brousseau, C. M., R. G. Randall \& M. G. Clark, 2005. Protocol for Boat Electrofishing in Nearshore Areas of the Lower Great Lakes: Transect and Point Survey Methods for Collecting Fish and Habitat Data, 1988 to 2002. Canadian Manuscript Report of Fisheries and Aquatic Sciences, Vol. 2702. Fisheries and Oceans Canada, Burlington: $x i+89$.

Cattaneo, A., G. Galanti, S. Gentinetta \& S. Romo, 1998. Epiphytic algae and macroinvertebrates on submerged and floating-leaved macrophytes in an Italian lake. Freshwater Biology 39: 725-740.

Colwell, R. K., 2013. EstimateS: Statistical estimation of species richness and shared species from samples. Version 9. User's Guide and application published at: http://www. purl.oclc.org/estimates. Accessed 20 April 2017.

Colwell, R. K., A. Chao, N. J. Gotelli, S. Y. Lin, C. X. Mao, R. L. Chazdon \& J. T. Longino, 2012. Models and estimators linking individual-based and sample-based rarefaction, extrapolation and comparison of assemblages. Journal of Plant Ecology 5: 3-21.

Cowx, I. G. \& P. Lamarque (eds), 1990. Fishing with Electricity: Applications in Freshwater Fisheries Management. Wiley, Cambridge.

Cowx, I. G. \& R. L. Welcomme (eds), 2004. Rehabilitation of Rivers for Fish. Fishing News Books, Blackwell Science, Oxford.

Dunham, J., A. Rosenberger, R. Thurow, C. Dolloff \& P. Howell, 2015. Chapter 8: coldwater fish in wadeable streams. In Standard Methods for Sampling North American Freshwater Fishes. American Fisheries Society, Bethesda: 119-138.

Egertson, C. J., J. A. Kopaska \& J. A. Downing, 2004. A century of change in macrophyte abundance and composition in response to agricultural eutrophication. Hydrobiologia 524: $145-156$.

Eklöv, A. \& A. Greenberg, 1998. Effects of artificial instream cover on the density of $0+$ brown trout. Fisheries Management and Ecology 5: 45-53.

Englund, G. \& B. Malmqvist, 1996. Effects of flow regulation, habitat area and isolation on the macroinvertebrate fauna of rapids in north Swedish rivers. Regulated Rivers: Research and Management 12: 433-445.

Fabris, M., S. Schneider \& A. Melzer, 2009. Macrophyte-based bioindication in rivers - a comparative evaluation of the reference index (RI) and the trophic index of macrophytes (TIM). Limnologica 39: 40-55.

Feldman, R. S., 2001. Taxonomic and size structures of phytophilous macroinvertebrate communities in Vallisneria and Trapa beds of the Hudson River, New York. Hydrobiologia 452: 233-245.

Finstad, A. G., S. Einum, T. Forseth \& O. Ugedal, 2007. Shelter availability affects behaviour, size-dependent and mean growth of juvenile Atlantic salmon. Freshwater Biology 52: $1710-1718$.

Fleming, I. A., 1996. Reproductive strategies of Atlantic salmon: ecology and evolution. Reviews in Fish Biology and Fisheries 6: 379-416.

Franklin, P., M. Dunbar \& P. Whitehead, 2008. Flow controls on lowland river macrophytes: a review. Science of the Total Environment 400: 369-378.

French, T. D. \& P. A. Chambers, 1997. Reducing flows in the Nechako River (British Columbia, Canada): potential response of the macrophyte community. Canadian Journal of Fisheries and Aquatic Sciences 54: 2247-2254.

Gabrielsen, S.-E., B. T. Barlaup, G. A. Halvorsen, O. R. Sandven, T. Wiers, G. B. Lehmann, H. Skoglund, B. Skår, T, Wiers, U. Pulg \& K. Vollset, 2011. "LIV" - livet i vassdragene. Langsiktige unders $\varnothing$ kelser av laks og sjøaure i Matreelva i perioden 2006-2011. LFI rapport nr. 187.

Garner, P., J. A. B. Bass \& G. D. Collett, 1996. The effects of weed cutting upon the biota of a large regulated river. Aquatic Conservation: Marine and Freshwater Ecosystems 6: 21-29.

Gilinsky, E., 1984. The role of fish predation and spatial heterogeneity in determining benthic community structure. Ecology 65: 455-468.

Gregg, W. W. \& F. L. Rose, 1985. Influences of aquatic macrophytes on invertebrate community structure, guild structure, and microdistribution in streams. Hydrobiologia 128: 45-56.

Groves, P. A. \& J. A. Chandler, 2005. Habitat quality of historic snake river fall Chinook salmon spawning locations and implications for incubation survival. Part 2: intra-gravel water quality. River Research and Applications 21: 469-483.

Habib, S. \& A. Yousuf, 2015. Effect of macrophytes on phytophilous macroinvertebrate community: a review. Journal of Entomology and Zoology Studies 3: 377-384.

Hammer, Ø., D. A. T. Harper \& P. D. Ryan, 2001. PAST: Paleontological Statistics software package for education and data analysis. Paleontologica electronica 4: 1-9.

Harrod, J. J., 1964. The distribution of invertebrates on submerged aquatic plants in a Chalk Stream. Journal of Animal Ecology 33: 335-348.

Haslam, S. M., 1978. River Plants. Cambridge University Press, Cambridge.

Heggenes, J., 1990. Habitat utilization and preferences in juvenile atlantic salmon (Salmo salar) in streams. Regulated Rivers: Research and Management 5: 341-354.

Heggenes, J. \& S. J. Saltveit, 2002. Effect of aquatic mosses on juvenile fish density and habitat use in the regulated River Suldalslagen, Western Norway. River Research and Applications 18: 249-264.

Hilt, S., S. Brothers, E. Jeppesen, A. J. Veraart \& S. Kosten, 2017. Translating regime shifts in shallow lakes into changes in ecosystem functions and services. Bioscience 67: 928-936.

Holm, S., 1979. A simple sequentially rejective multiple test procedure. Scandinavian Journal of Statistics 6: 65-70.

Hussner, A., I. Stiers, M. J. J. M. Verhofstad, E. S. Bakker, B. M. C. Grutters, J. Haury, J. L. C. H. van Valkenburg, G. Brundu, J. Newman, J. S. Clayton, L. W. J. Anderson \& D. Hofstra, 2017. Management and control methods of invasive alien freshwater aquatic plants: a review. Aquatic Botany 136: 112-137.

Hynes, H. B. N., 1970. The Ecology of Running Waters, Vol. 1. Liverpool University Press, Liverpool.

Ibáñez, C. \& J. Peñuelas, 2019. Changing nutrients, changing rivers. Science 365: 637-638.

Janáĉ, M. \& P. Jurajda, 2007. A comparison of point abundance and continuous sampling by electrofishing for age- 0 fish in a channelized lowland river. North American Journal of Fisheries Management 27: 1119-1125. 
Johnsen, B. O., J. V. Arnekleiv, L. Asplin, B. T. Barlaup, T. F. Næsje, B. O. Rosseland, S. J. Saltveit \& A. Tvede, 2010. Hydropower Development - Ecological Effects Atlantic Salmon Ecology. Wiley-Blackwell, Hoboken: 351-385.

Jonsson, B. \& N. Jonsson, 2011. Ecology of Atlantic Salmon and Brown Trout: Habitat as a Template for Life Histories, Vol. 33. Springer, Dordrecht.

Kagami, M., J. Nishihiro \& T. Yoshida, 2019. Ecological and limnological bases for management of overgrown macrophytes: introduction to a special feature. Limnology 20: $1-2$.

Keast, A., 1984. The introduced aquatic macrophyte, Myriophyllum spicatum, as habitat for fish and their invertebrate prey. Canadian Journal of Zoology-Revue Canadienne De Zoologie 62: 1289-1303.

Kern-Hansen, U., 1978. Drift of Gammarus pulex L. in relation to macrophyte cutting in four small Danish lowlandstreams. SIL Proceedings, 1922-2010 20: 1440-1445.

Killgore, K. J., R. P. Morgan \& N. B. Rybicki, 1989. Distribution and abundance of fishes associated with submersed aquatic plants in the Potomac River. North American Journal of Fisheries Management 9: 101-111.

Kohler, J., J. Hachol \& S. Hilt, 2010. Regulation of submersed macrophyte biomass in a temperate lowland river: interactions between shading by bank vegetation, epiphyton and water turbidity. Aquatic Botany 92: 129-136.

Krecker, F. H., 1939. A comparative study of the animal population of certain submerged aquatic plants. Ecology 20: $553-562$.

Lan, Y., B. Cui, X. Li, Z. Han \& W. Dong, 2010. The determinants and control measures of the expansion of aquatic macrophytes in wetlands. Procedia Environmental Sciences 2: 1643-1651.

Laughton, R., P. J. Cosgrove, L. C. Hastie \& I. Sime, 2008. Effects of aquatic weed removal on freshwater pearl mussels and juvenile salmonids in the River Spey, Scotland. Aquatic Conservation: Marine and Freshwater Ecosystems 18: 44-54.

Lucassen, E., A. J. P. Smolders \& J. G. M. Roelofs, 2012. Liming induces changes in the macrophyte vegetation of Norwegian softwater lakes by mitigating carbon limitation: results from a field experiment? Applied Vegetation Science 15: 166-174.

Lucassen, E., J. G. M. Roelofs, S. C. Schneider \& A. J. P. Smolders, 2016. Long-term effects of liming in Norwegian softwater lakes: the rise and fall of bulbous rush (Juncus bulbosus) and decline of isoetid vegetation. Freshwater Biology 61: 769-782.

McAbendroth, L., P. M. Ramsay, A. Foggo, S. D. Rundle \& D. T. Bilton, 2005. Does macrophyte fractal complexity drive invertebrate diversity, biomass and body size distributions? Oikos 111: 279-290.

Merz, J. E., J. R. Smith, M. L. Workman, J. D. Setka \& B. Mulchaey, 2008. Aquatic macrophyte encroachment in chinook salmon spawning beds: lessons learned from gravel enhancement monitoring in the lower Mokelumne River, California. North American Journal of Fisheries Management 28: 1568-1577.

Moe, T. F., 2012. Nuisance Growth of Juncus bulbosus in Lakes and Rivers - Experimental and Observational Studies. University of Oslo.
Moe, T. F., A. K. Brysting, T. Andersen, S. C. Schneider, O. Kaste \& D. O. Hessen, 2013. Nuisance growth of Juncus bulbosus: the roles of genetics and environmental drivers tested in a large-scale survey. Freshwater Biology 58: 114-127.

Monahan, C. \& J. M. Caffrey, 1996. The effect of weed control practices on macroinvertebrate communities in Irish Canals. Hydrobiologia 340: 205-211.

Mork, J. \& T. G. Heggberget, 1984. Eggs of Atlantic salmon (Salmo salar L.) and Trout (S. trutta L.); identification by phosphoglucoisomerase zymograms. Aquaculture Research 15: 59-65.

Nelva, A., H. Persat \& D. Chessel, 1979. Une nouvelle méthode d'étude des peuplements ichtyologiques dans les grands cours d'eau par échantillonnage ponctuel d'abondance. Comptes Rendus de l'Académie des Sciences 289: 1295-1298.

Ochs, K., R. P. Rivaes, T. Ferreira \& G. Egger, 2018. Flow management to control excessive growth of macrophytes an assessment based on habitat suitability modeling. Frontiers in Plant Science. https://doi.org/10.3389/fpls. 2018.00356.

Petr, T., 2000. Interactions Between Fish and Aquatic Macrophytes in Inland Waters. A Review. Fisheries Technical Paper No. 396. Food and Agriculture Organization of the United Nations, Rome.

Proćków, J., 2008. What is Juncus bulbosus subsp. kochii (Juncaceae) and does it really exist? A taxonomic revision of bulbous rush subspecies. Botanical Journal of the Linnean Society 156: 501-512.

Quadroni, S., G. Crosa, G. Gentili \& P. Espa, 2017. Response of stream benthic macroinvertebrates to current water management in Alpine catchments massively developed for hydropower. Science of the Total Environment 609: 484-496.

R Core Team, 2017. R: A Language and Environment for Statistical Computing. R Foundation for Statistical Computing, Vienna.

Resh, V. H., A. V. Brown, A. P. Covich, M. E. Gurtz, H. W. Li, G. W. Minshall, S. R. Reice, A. L. Sheldon, J. B. Wallace \& R. C. Wissmar, 1988. The role of disturbance in stream ecology. Journal of the North American Benthological Society 7: 433-455.

Richardson, W. B., 1992. Microcrustacea in flowing water: experimental analysis of washout times and a field test. Freshwater Biology 28: 217-230.

Roelofs, J. G. M., 1983. Impact of acidification and eutrophication on macrophyte communities in soft waters in The Netherlands I. Field observations. Aquatic Botany 17: 139-155.

Rørslett, B., 1988. Aquatic weed problems in a hydroelectric river: the R. Otra, Norway. Regulated Rivers: Research and Management 2: 25-37.

Rørslett, B., M. Mjelde \& S. W. Johansen, 1989. Effects of hydropower development on aquatic macrophytes in norwegian rivers: present state of knowledge and some case studies. Regulated Rivers: Research and Management 3: 19-28.

Rose, N. L., 2007. Lochnagar : The Natural History of a Mountain Lake. Springer, Dordrecht. 
Rosine, W. N., 1955. The distribution of invertebrates on submerged aquatic plant surfaces in Muskee Lake, Colorado. Ecology 36: 308-314.

Roussel, J. M., A. Bardonnet, J. Haury, J. L. Bagliniere \& E. Prevost, 1998. Aquatic plant and fish assemblage: a macrophyte removal experiment in stream riffle habitats in a lowland salmonid river (Brittany, France). Bulletin Francais De La Peche Et De La Pisciculture. https://doi. org/10.1051/kmae:1998035.

Schneider, S. C., T. F. Moe, D. O. Hessen \& O. Kaste, 2013. Juncus bulbosus nuisance growth in oligotrophic freshwater ecosystems: different triggers for the same phenomenon in rivers and lakes? Aquatic Botany 104: 15-24.

Scholten, M., 2003. Efficiency of point abundance sampling by electro-fishing modified for short fishes. Journal of Applied Ichthyology 19: 265-277.

Schultz, R. \& E. Dibble, 2012. Effects of invasive macrophytes on freshwater fish and macroinvertebrate communities: the role of invasive plant traits. Hydrobiologia 684: 1-14.

Scrine, J., M. Jochum, J. S. Olafsson \& E. J. O’Gorman, 2017. Interactive effects of temperature and habitat complexity on freshwater communities. Ecology and Evolution 7: 9333-9346.

Shi, M., J. Y. Li, W. G. Zhang, Q. Zhou, Y. H. Niu, Z. H. Zhang, Y. Gao \& S. H. Yan, 2019. Contrasting impact of elevated atmospheric $\mathrm{CO}_{2}$ on nitrogen cycle in eutrophic water with or without Eichhornia crassipes (Mart.) Solms. Science of the Total Environment 666: 285-297.

Skoglund, H., B. Barlaup \& T. Wiers, 2006. Forekomst av krypsiv på gyteområder hos laks i Mandalselva. LFI Uni Miljø notat, 16.

Svedang, M. U., 1992. Carbon dioxide as a factor regulating the growth dynamics of Juncus bulbosus. Aquatic Botany 42: 231-240.

Swales, S., 1982. Impacts of weed-cutting on fisheries: an experimental study in a small lowland river. Aquaculture Research 13: 125-137.
Thomaz, S. M. \& E. R. da Cunha, 2010. The role of macrophytes in habitat structuring in aquatic ecosystems: methods of measurement, causes and consequences on animal assemblages' composition and biodiversity. Acta Limnologica Brasiliensia 22: 218-236.

Valiente, A. G., F. Juanes, P. Nunez \& E. Garcia-Vazquez, 2010. Brown trout (Salmo trutta) invasiveness: plasticity in life-history is more important than genetic variability. Biological Invasions 12: 451-462.

Verhofstad, M. J. J. M. \& E. S. Bakker, 2019. Classifying nuisance submerged vegetation depending on ecosystem services. Limnology 20: 55-68.

Verhofstad, M. J. J. M., M. M. Alirangues Núñez, E. P. Reichman, E. van Donk, L. P. M. Lamers \& E. S. Bakker, 2017. Mass development of monospecific submerged macrophyte vegetation after the restoration of shallow lakes: roles of light, sediment nutrient levels, and propagule density. Aquatic Botany 141: 29-38.

Vinson, M. R. \& C. P. Hawkins, 1998. Biodiversity of stream insects: variation at local, basin, and regional scales. Annual Review of Entomology 43: 271-293.

Warfe, D. M. \& L. A. Barmuta, 2004. Habitat structural complexity mediates the foraging success of multiple predator species. Oecologia 141: 171-178.

Young, P. S., J. J. Cech \& L. C. Thompson, 2011. Hydropowerrelated pulsed-flow impacts on stream fishes: a brief review, conceptual model, knowledge gaps, and research needs. Reviews in Fish Biology and Fisheries 21: 713-731.

Publisher's Note Springer Nature remains neutral with regard to jurisdictional claims in published maps and institutional affiliations. 